\title{
Primer immundefektus esetén előforduló onkohematológiai kórképek
}

\author{
Müller Judit dr. - Kovács Gábor dr. \\ Semmelweis Egyetem, Általános Orvostudományi Kar, II. Gyermekgyógyászati Klinika, Budapest
}

\begin{abstract}
A primer immundefektusok (PID) ritka, veleszületett, többnyire öröklődő immunhiányos állapotok. Körülbelül 350 gén érintettsége mutatható ki ezen betegségeknél, amelynek következménye az immunsejtek számbeli és/vagy funkcionális csökkenése. A primer immunhiány gyakorisága napjainkban egyre nő. A PID kezelésében jelentős eredményeket értek el az immunglobulinpótlás és az őssejtterápia bevezetésével, ennek köszönhetően ezen betegek hosszú távú túlélése is megnövekedett. Mivel a PID-es betegek tovább élnek, mint néhány évtizeddel ezelött, több rosszindulatú daganatos megbetegedést is diagnosztizálunk náluk. PID-ben szenvedő gyermekek és felnőttek körében is a malignitás áll a fertőzések után a halálokok között a második helyen. Jelen munkánk során bemutatjuk a PID-es betegségekben előforduló gyakoribb rosszindulatú betegségeket és azok klinikai jellemzőit.

Orv Hetil. 2018; 159(49): 2073-2078.
\end{abstract}

Kulcsszavak: primer immundefektus, malignitás, lymphoma, kromoszómatörékenység

\section{Primary immunodeficiencies and haemato-oncology}

Primary immunodeficiencies (PID) are rare, congenital disorders, often associated with genetic defects in the immune system. According to our current knowlegde, about 350 genes are involved in distinct immunodeficiency disorders. In PIDs at least one, and often more, immune component is impaired, missing, or has an inappropriate function. The prevalence of PID has been increasing. Due to advances in the treatment of PID, especially immunoglobulin replacement therapy and stem cell transplantation, the life expectancy of patients is longer. As patients with PID live longer, malignancies are diagnosed more commonly. Patients with PID are at an increased risk of malignancy compared with the normal population. Malignancy is the second most common cause of death in these patients after infections. The aim of this article is to review the malignancies and their clinical relevance in patients with PID.

Keywords: primary immunodeficiency, malignancy, lymphoma, chromosomal breakage

Müller J, Kovács G. [Primary immunodeficiencies and haemato-oncology]. Orv Hetil. 2018; 159(49); $2073-2078$.

(Beérkezett: 2018. július 4.; elfogadva: 2018. szeptember 10.)

\section{Rövidítések}

$\mathrm{AT}=$ ataxia teleangiectasia ATM $=$ az ataxia teleangiectasia gén mutációja; CTL = cytotoxicus T-lymphocyta; CVID $=(\mathrm{com}-$ mon variable immunodeficiency) variábilis immunhiány; DLBCL = diffúz, nagy B-sejtes lymphoma; DNS = dezoxiribonukleinsav; $\mathrm{EBV}=$ Epstein-Barr-vírus; $\mathrm{HBV}=$ hepatitis B-vírus; $\mathrm{HCV}=$ hepatitis $\mathrm{C}$-vírus; $\mathrm{HD}=$ Hodgkin-kór; $\mathrm{HPV}=$ humán papillomavírus; HTLV = humán T-sejtes leukaemialymphoma vírus; $\mathrm{KS}=$ Kaposi-sarcoma; $\mathrm{MALT}=$ (mucosa-associated lymphoid tissue) mucosaasszociált lymphoid szövet; NHL = non-Hodgkin-lymphoma; PID = (primary immunodeficiency) primer immundefektus; SAP = jelátviteliadapter-protein; SCID = (severe combined immunodeficiency) súlyos kombinált immunhiányos állapot; SLAM = (signaling lymphocyte activating molecule) jeladó lymphocyta aktiváló molekula;
WAS = Wiskott-Aldrich-szindróma; WASP = WAS-protein; $\mathrm{XLP}=(\mathrm{X}$-linked lymphoproliferative disease $) \mathrm{X}$-kromoszómához kötött lymphoproliferativ szindróma

Az első közlemény 1963-ban jelent meg a primer immundefektusban (PID) szenvedő betegeknél előforduló malignitásról [1]. Jelenleg a PID-ben szenvedő gyermekek és felnőttek körében is a malignitás áll a fertőzések után a halálokok között a második helyen. A PID kezelésében jelentős eredményeket értek el az immunglobulinpótlás bevezetésével, ennek köszönhetően a betegek hosszú távú túlélése is megnövekedett [2]. Mivel a PIDes betegek tovább élnek, mint néhány évtizeddel ezelőtt, 
egyre több rosszindulatú daganatos megbetegedést diagnosztizálunk náluk.

A PID-hez köthető malignitások több mint fele két betegségcsoportban fordul elő: 30\% ataxia teleangiectasia (AT) és $24 \%$ common variable immundeficiency (CVID) esetében. Az esetek további 30\%-át Wiskott-Aldrichszindrómában (WAS), súlyos kombinált immunodeficientiánál (SCID) és szelektív IgA-hiányban diagnosztizáljuk.

\section{Epidemiológia és előfordulási valószínüség}

Az alapbetegség ritkasága, a relatív alacsony betegszám, a nehezen összehasonlítható betegcsoportok miatt átfogó tanulmányok, pontos adatok nem állnak rendelkezésünkre a rosszindulatú daganatos megbetegedések előfordulási valószínúségéről, de irodalmi adatok alapján ez körülbelül 4-25\%-ra tehető [3].

Jonkman-Berk és mtsai 754 holland PID-es beteg adatait dolgozták fel 2009 és 2012 között, és a betegek közel 10\%-a malignitásban is szenvedett [4]. Az átlag holland populációhoz képest a malignitás kialakulásának relatív rizikója 2,3-szeres volt a PID-es betegek esetében, és ez a szám 10-szeresre emelkedett bizonyos szolid daganatok (például pajzsmirigy, thymus) és hematológiai malignitások (például leukaemia, lymphoma) esetében.

A Minnesotai Egyetem Immunodeficientia és Rák Regiszterének adatai alapján a PID-es betegeknél a két leggyakoribb malignitás a non-Hodgkin-lymphoma (NHL) és a Hodgkin-kór (HD). Ez előbbi 48,6\%-a, az utóbbi 10\%-a a PID-es betegek daganatainak [5]. A PID-es betegekben a diffúz, nagy B-sejtes lymphoma (DLBCL) a leggyakoribb NHL-altípus.

Az Ausztrálázsiai Klinikai Immunológiai és Allergológiai Társaság (Australasian Society of Clinical Immunology and Allergy) PID-regiszterének eredményeit 2010ben publikálták, melyeket a nemzeti rák- és halálozási regiszter adataival vetettek össze [6]. A mai napig talán ez a legnagyobb $(n=1132)$ esetszámot feldolgozó tanulmány. Ebben a vizsgálatban a PID-es betegek relatív rizikója rosszindulatú daganat kialakulására 1,6-szeres volt 16 éves átlagkövetési időnél. A három leggyakrabban diagnosztizált daganat az NHL (28\%), a leukaemia és a gyomorrák volt.

\section{Patomechanizmus}

\section{A malignitások magasabb elöfordulási valószinüségének okai}

A malignitás kialakulásában szerepet játszó mechanizmusok közé tartozik a genetikai instabilitás, a genetikai prediszpozíció, az immundiszreguláció, az onkogén tulajdonságokkal bíró vírusok csökkent eliminálása, illetve iatrogén okok is [7]. A malignitások a sejtek folyamatos és kontrollálatlan osztódása által keletkeznek. Ebben jelentős szerepet játszanak az adott sejtek szaporodását és apoptózisát befolyásoló gének, valamint az ezek aktivitását és inaktiválását befolyásoló tényezők hibái. A génhibák lehetnek öröklöttek és szerzettek is. PID-ben a génhibák mellett természetesen a szervezet csökkent immunválasza is biztosan szerepet játszik a daganat kialakulásában mind az onkogén vírusok, mind a premalignus és malignus sejtek csökkent eliminációján keresztül. A PIDes esetek egy részében a daganatok pontos patofiziológiája nem ismert, de a különböző alcsoportokban néhány konkrét ok feltételezhető. Például a sejtmediált tumorsurveillance sérülése (kombinált immundeficientiák), a cytokinesis defektusa (X-hez kötött neutropenia, WAS), a vírusfertőzött sejtek csökkent kontrollja (X-hez kötött lymphoproliferativ betegség [XLP]), a sejtciklus kontrolljának sérülése (porc-haj hypoplasia szindróma), a genotoxicus ágensekkel szembeni csökkent válasz (DNS-repair-zavarok), sérült apoptózis (autoimmun lymphoproliferativ szindróma), patogének csökkent eliminálása túlaktivált gyulladásos válasszal (CVID, X-hez kötött agammaglobulinaemia, CD40-ligand-deficientia) (1. táblázat) [8]. A legújabb genetikai vizsgálatok alapján derült fény arra, hogy bizonyos PID-ekben a daganat kialakulásáért ugyanaz a molekuláris eltérés felelős [9]. Ennek megfelelően beszélhetünk úgynevezett intrinszik kiváltó okokról, vagyis a malignus sejttranszformáció ugyanabban a sejtfajtában alakul ki, amelyik a PID-ben érintett, vagy egy másik sejtfajtában, de azonos a molekuláris alapja a malignitásnak és a PID-nek. Ezen csoportosítás alapján a PID-es betegek tumorprediszpozíciójának extrinszik oka lehet: vírusfertőzés indukálta transzformáció, krónikus szöveti gyulladás, valamint csökkent sejtmediált tumorsurveillance.

A genetikai instabilitás egyik legismertebb oka a fokozott kromoszómatörékenység. A fokozott kromoszómatörékenységgel járó szindrómák genetikai megbetegedések, amelyekre az immundeficientián kívül az ionizáló sugárzással szembeni fokozott érzékenység, a daganatos megbetegedések magasabb előfordulási aránya, neurológiai eltérések és a két-szálú DNS hibajavító mechanizmusainak károsodása jellemző. A különböző klinikai megjelenési formák hátterében olyan genetikai eltérések állnak, amelyek következtében a DNS-szálban létrejövő töréseket, hibákat normális esetben kijavító mechanizmusok sérülnek. Ezen betegségcsoport jól ismert példái az AT, a Fanconi-anaemia, a Nijmegen breakage szindróma és a Bloom-szindróma [10]. Valószínúleg hasonló mechanizmusok is szerepet játszanak WAS és az epidermodysplasia verruciformis alapbetegségek mellett kialakuló malignitásokban is [11].

PID esetében az immunrendszer csökkent védelmi funkciója révén a vírusok okozta fertőzésekkel is számolnunk kell. Ki kell emelnünk azokat a vírusokat, amelyek a normálpopulációban is jelentős szerepet játszanak a malignitások kialakulásában: Epstein-Barr- (EBV), hepatitis B- (HBV), hepatitis C- $(\mathrm{HCV})$, humán papilloma- (HPV), human T-sejtes lymphotrop (HTLV) és Kaposi-sarcomához (KS) asszociált vírus [12]. Ilyen ismert 


\begin{tabular}{|c|c|c|}
\hline Betegség & Malignitáshoz vezetó feltételezett ok & Malignitások \\
\hline \multicolumn{3}{|c|}{ Kombinált (B- és T-sejt-) immunhiányos állapotok } \\
\hline Súlyos kombinált immundefektus & $\begin{array}{l}\text { Az immunrendszer csökkent múködése } \\
\text { és sérült víruselimináció (EBV) }\end{array}$ & $\begin{array}{l}\text { NHL (EBV-asszociált, DLBCL), HD } \\
\text { Leukaemia, adenocarcinoma, vese-, tüdő-, leiomyosarcoma }\end{array}$ \\
\hline \multicolumn{3}{|l|}{ Elsődlegesen antitesthiány-állapotok } \\
\hline Agammaglobulinaemia & Csökkent immunsurveillance & $\begin{array}{l}\text { Leukaemia, lymphoma } \\
\text { Gyomor- és vastagbél-adenocarcinoma }\end{array}$ \\
\hline Variábilis immundefektus & Tumorszuppresszor gének defektusa & $\begin{array}{l}\text { NHL, carcinoma (gyomor-bél, emlő, hólyag, méhnyak, } \\
\text { tonsilla, bőr, vulva); MALT, EBV indukálta extranodalis } \\
\text { DLBCL, ritkábban HD }\end{array}$ \\
\hline Hiper-IgM-szindróma & $\begin{array}{l}\text { Elhúzódó Cryptosporodium, HBV/HCV } \\
\text { és CMV-fertőzés }\end{array}$ & $\begin{array}{l}\text { NHL (EBV-asszociált); carcinoma (hasnyálmirigy, } \\
\text { hepatocellularis, epeút, neuroendokrin), HD }\end{array}$ \\
\hline Szelektív IgA-hiány & Csökkent immunsurveillance & $\begin{array}{l}\text { Lymphoma, gyomoradenocarcinoma, enteropathia } \\
\text { asszociálta T-sejtes lymphoma }\end{array}$ \\
\hline \multicolumn{3}{|l|}{ Jól definiált immunhiány-szindrómák } \\
\hline Wiskott-Aldrich-szindóma & $\begin{array}{l}\text { Az immunrendszer csökkent múködése } \\
\text { és sérült víruselimináció }\end{array}$ & $\begin{array}{l}\text { DLBLC, NHL (gége vagy központi idegrendszer); } \\
\text { ritkábban leukaemia, MDS, KS, glioma, simaizomtumor }\end{array}$ \\
\hline Ataxia teleangiectasia & DNS-repair-zavar & $\begin{array}{l}\text { T-sejtes lymphoblastos leukaemia/lymphoma, HD } \\
\text { Hámeredetú carcinoma, agytumor, HCC }\end{array}$ \\
\hline Nijmegen breakage szindróma & DNS-repair-zavar & $\begin{array}{l}\text { Lymphoma (fóleg B- vagy T-sejtes, ritkán HD), AML, } \\
\text { agytumor, hámeredetú carcinoma }\end{array}$ \\
\hline Bloom-szindróma & DNS-repair-zavar & Leukaemia, lymphoma, bőrrák, hámeredetû́ carcinoma \\
\hline Porc-haj hypoplasia & & NHL, basalioma \\
\hline Hiper-IgE-szindróma & Tumorszuppresszor gén defektusa & Lymphoma, tüdőadenocarcinoma, laphámrák \\
\hline \multicolumn{3}{|l|}{ Immunregulációs zavarok } \\
\hline Chédiak-Higashi-szindróma & & Lymphoma \\
\hline Hermansky-Pudlak-szindróma & & Lymphoma \\
\hline $\begin{array}{l}\text { Familiaris haemophagocytás } \\
\text { lymphohistiocytosis 2-es típusa }\end{array}$ & & Lymphoma \\
\hline $\begin{array}{l}\text { Autoimmun lymphoproliferativ } \\
\text { szindróma }\end{array}$ & Tumorszuppresszor gén defektusa & NHL, ritkábban leukaemia, HD, glioma \\
\hline $\begin{array}{l}\text { X-hez kötött lymphoproliferativ } \\
\text { betegség }\end{array}$ & $\begin{array}{l}\text { Az immunrendszer csökkent múködése } \\
\text { és sérült víruselimináció (EBV) }\end{array}$ & $\begin{array}{l}\text { EBV indukálta high-grade NHL (bél) } \\
\text { Ritkábban T-sejtes NHL, EBV-negatív NHL, HD }\end{array}$ \\
\hline
\end{tabular}

$\mathrm{AML}=$ akut myeloid leukaemia $\mathrm{CMV}=$ cytomegalovirus DLBCL = diffúz nagy B-sejtes lymphoma; $\mathrm{EBV}=\mathrm{Epstein}-\mathrm{Barr}$-vírus; HBV = hepatitis B-vírus; HCC = hepatocelullaris carcinoma; HCV = hepatitis C-vírus; HD = Hodgkin-kór; $\mathrm{KS}=$ Kaposi-sarcoma; MALT = mucosaasszociált lymphoid szövet; $\mathrm{MDS}=$ myelodysplasiás szindróma; NHL = non-Hodgkin-lymphoma

onkogén vírus okozta fertőzés következtében a virális genom átíródik a gazda DNS-ében, ezáltal protoonkogéneket aktiválnak, tumorszuppresszor géneket inaktiválnak, valamint bizonyos növekedési faktorokat stimulálnak, amelyek a sejtek malignus transzformációjához vezethetnek.

$\mathrm{Az}$ immunhiányban szenvedő betegek fokozottan érzékenyek az EBV okozta fertőzésekkel szemben, akár primeren, cseppfertőzés útján, akár szervátültetés vagy vérkészítmény transzfúziója során fertőződtek meg. Az EBV megfertőzheti a T-lymphocytákat és az epithelsejteket is, de speciális affinitása van a B-sejtekhez, melyek egyben a vírus rezervoárjai az emberi szervezetben. Az EBV erôs immunstimulációt jelent: eleinte a B-sejtekben EBV-specifikus és EBV-nemspecifikus antitestek termelését indukálja, majd ezt követően a cytotoxicus T-lymphocyták (CTL) aktiválódnak. Ezen CTL-ek nem megfelelő múködése teszi lehetôvé a B-sejtek proliferatióját, ami a B-sejtes polyclonalis hyperplasiája mellett akár malignus transzformációhoz vezethet, és ez utóbbi által agresszív, magas malignitású lymphoma alakul ki [13].

\section{A PID-ben elöforduló malignitások jellemzői}

A PID-es betegekben előforduló malignitások döntő többsége disszeminált vagy előrehaladottabb stádiumú és ezáltal rosszabb prognózisú, valamint jelentôs részük valamilyen fertőző ágenssel (például EBV, HPV, HBV, HCV) hozható összefüggésbe [14].

A PID-es betegekben előforduló rosszindulatú daganatos megbetegedéseknek vannak bizonyos speciális jellemzőik az immunkompetens betegekéivel összehasonlítva, különösen NHL és HD esetében [15]. A BFM-munkacsoport 1413, NHL-s gyermek adatát dolgozta fel, és közülük 19-nek volt PID-je. A diagnózis felállításakor a PID-es gyerekek átlagéletkora szignifikánsan alacsonyabb volt az immundeficientiában nem szenvedőkénél (7,8 év versus 9,3 év). A PID-ben előforduló NHL-ek döntő részes B-sejtes eredetű, magas osztódási rátával és gyakran extranodalis (általában gyomor-bél rendszer, tüdő vagy központi idegrendszer) érintettséggel prezentálódik. Említésre méltó, hogy az NHL-es esetek 30-60\%-ának kialakulása aktuális EBV-fertőzéssel 
összefüggésbe hozható, különösen a B-sejtes NHL-ek [16]. NHL férfiakban gyakrabban alakul ki, illetve az átlagéletkor a malignus megbetegedés diagnosztizálásakor alacsonyabb, mint az átlagpopulációban. Az NHL-hez hasonlóan a HD is korábbi életkorban fordul elő PIDben. Egy vizsgálatban 120, HD-ban szenvedő gyerek közül 20 esetben PID is jelen volt, és ez utóbbi 20 beteg átlagéletkora 7,8 év volt, míg a többi 100 esetében ez 11,5 év volt [17]. A HD prognózisa rosszabb PID-es gyermekek esetében, mint a diagnózis felállításakor még immunkompetensekben [18].

\section{Az egyes kórképek esetében előforduló malignitások}

\section{Ataxia teleangiectasia (AT)}

Az AT a fokozott kromoszómatörékenységgel járó szindrómák közé tartozik. Autoszomális recesszív öröklődést mutat, és a p53-aktivitásban nélkülözhetetlen ataxia teleangiectasia gén mutációja (ATM) okozza. Ezen mutáció következtében a sejtosztódáskor vagy sugárzás okozta DNS-károsodáskor keletkező hibákat nem ismeri fel a szervezet, azokat nem javítja ki, illetve a sejt nem pusztul el. Ezért ezek a betegek extrém érzékenyek ionizáló sugárzásra, illetve malignitás kialakulására. Az AT-s betegek 25-35\%-ának lesz malignitása élete folyamán [19]. Gyermekekben főként T-sejtes akut lymphoblastos leukaemia vagy lymphoma fordul elő, míg a myeloid leukaemia igen ritka. Akikben felnőttkorban manifesztálódik a tumor, ott a lymphoid malignitások mellett szolid daganatokkal is számolni kell (emlő-, hepatocellularis, gyomor adeno-, nyelőcső-carcinoma, agytumor és basalioma) [20]. Az ATM-gén szükséges az egyik emlőcarcinomát (BRCAl) okozó tumorszuppresszor gén megfelelő múködéséhez is. Az ATM-gén mutációját homozigóta vagy heterozigóta formában hordozókban emelkedett az emlődaganat előfordulási valószínúsége [21]. Normál humán sejtet érő sugárzást követően többek között a sejtciklus-ellenőrző pontok (cell-cycle checkpoint) aktiválásán keresztül válaszol a sejt. Az AT-s betegek sejtjeit ex vivo vizsgálva a sejtet érő sugárzás hatására ezen aktiválási képesség jelentősen elmarad az egészséges sejtekéhez képest [22].

\section{Variábilis immundefektus (CVID)}

A CVID prevalenciája 1/10 000-25 000. Akár gyermek-, akár felnőttkorban diagnosztizálják, jellemző eltérés a B-sejtek differenciálódásának és az immunglobulintermelésnek a különböző mértékű sérülése [23]. CVID esetében számos genetikai mutáció ismert, a betegség molekuláris háttere ennek ellenére a legtöbb esetben tisztázatlan, valamint a malignus transzformáció kialakulásához vezető folyamatok sem mindig egyértelműek [24]. A CVID-hez 10-15\%-ban társulnak malignitások, a leggyakrabban lymphoma, gyomor- és bőrcarcinomák [25]. A gyomorrák kialakulásában speciális lokális okok szerepe is felmerül, mint a gyomorban csökkent IgA-termelés és achlorhydria, melyek elősegíthetik a Helicobacter pylori kolonizációját. Ez utóbbi a gyomornyálkahártya krónikus gyulladását okozza, amely hozzájárul a carcinogenesishez: a gyomorcarcinoma mellett MALT(mucosa-associated lymphoid tissue) lymphoma megjelenésével is számolni kell [6]. Ebben a betegcsoportban a MALT-lymphoma a leggyakrabban monoclonalis és agresszív B-sejtes lymphomára jellemző klinikai képet mutat; felnőttekben gyakran, de gyermekkorban csak igen ritkán fordul elő. Azon gyermekekben, akikben a CVID 16 éves koruk előtt manifesztálódik, a tumorok előfordulási valószínüsége $2,5 \%$, míg akikben később derül fény a CVID-re, ott 8,5\% [26]. CVID-es betegekben a humán herpeszvírus- 8 is potenciálisan szerepet játszhat lymphoproliferativ megbetegedések kialakulásában [27].

\section{Wiskott-Aldrich-szindróma (WAS)}

A WAS X-kromoszómához kötött öröklődést mutató kombinált immundeficientia, amelynek hátterében a WAS-proteint (WASP) kódoló gén mutációja áll [28]. A WASP mindegyik haemotopoeticus sejtvonalban kimutatható, és fó funkciója az aktin-cytoskeleton rendszer múködésének szabályozása. Egyes szerzők feltételezik a WASP direkt szerepét a genom stabilitásában, de ismert, hogy WAS-betegekben a malignitások kialakulásának fó oka nem a genetikai instabilitás [29]. Malignitások előfordulási valószínüsége ebben a betegcsoportban 13$22 \%[30,31]$. Daganatok már gyermekkorban is manifesztálódhatnak, de sokkal gyakrabban észleljük tinédzser-, illetve fiatal felnőtt korban. WAS esetén a leggyakrabban lymphoreticularis malignitások fordulnak elő: EBV-asszociált B-sejtes NHL, leukaemia és myelodysplasia. Egyéb tumorok: kisagyi astrocytoma, KS és ritkábban rhabdomyosarcoma [32]. A WAS-hoz asszociált malignitások prognózisa rossz [30]. WAS-ban a betegek 2 éves teljes túlélése $<5 \%$ [33], míg a Pai által végzett felmérésben a WAS lymphomájának diagnosztizálása és a beteg halála között átlagban <1 év telik el [34].

\section{Súlyos kombinált immundeficientia (SCID)}

A kombinált immundefektusokon belül - ahol mind a cellularis, mind a humoralis immunválasz csökkent - a SCID a legsúlyosabb formák közé tartozik [35]. Az esetek több mint fele X-kromoszómához kötött; fiúkban háromszor gyakoribb, mint leányokban. Ha nem kerül újszülött- vagy fiatal csecsemő korban felismerésre, a SCID 1-2 éven belül letális kimenetelü. A betegség klinikai tünetei az első élethetekben, de legkésőbb a 3-4. élethónapban mutatkoznak. A SCID heterogén betegségcsoport, melyben a T-sejt-hiány mellett a B- és NKsejtek érintettsége változó. A malignitás gyakorisága SCID esetén $8-10 \%$. Ebben a betegcsoportban is a leg- 
gyakoribb, az esetek közel háromnegyedében előforduló malignitás az EBV-hez köthető NHL. Ritkábban HD és leukaemiák is előfordulhatnak. A SCID-nek kuratív terápiás megoldása az allogénőssejt-transzplantáció. Ilyen esetekben azonban poszttranszplantációs lymphoproliferativ betegség (PTLD) előfordulásával is számolni kell.

\section{X-hez kötött lymphoproliferativ betegség (XLP)}

Az XLP, más néven Duncan-betegség X-kromoszómához kötött, recesszíven öröklődő, súlyos T-sejtes immundeficientia, amelyre az EBV-fertőzéssel szembeni fokozott fogékonyság és az EBV elleni védekezőképesség hiánya jellemző. Genetikai háttere az X-kromoszóma hosszú karján lokalizált SH2DlA-gén hibája. Az SH2DlA-gén az úgynevezett SAP-t, vagyis SLAM-hez (signaling lymphocyte activating molecule) asszociált proteint kódolja. A SAP a thymocytákban, a T- és NKsejtekben expresszálódik, és mutációja/hiánya esetén károsodik ezen sejtek cytotoxicus aktivitása és ezáltal többek között az EBV-fertőzött proliferáló sejtek kontrollja. A SAP-nak jelentős szerepe van a T- és az antigénprezentáló, valamint az NK- és célsejtek közötti interakcióban. A klinikailag súlyos, fulmináns, sokszor letális EBV-fertőzést gyakran májelégtelenség és haemophagocytosis kíséri. Az XLP-s betegek SAP/SH2DlA génjein elvégzett újabb kutatások szerint ezen betegcsoportban a dysgammaglobulinaemia és a B-sejtes lymphoma kialakulásának nem feltétele minden esetben az EBV-fertőzés [36]. Az XLP-s betegek közel harmadának élete során valamikor B-sejtes lymphomája alakul ki, amely jól reagál a standard kemoterápiára, azonban relapsus vagy más típusú második lymphoma is előfordulhat $[37,38]$. XLP esetében egyéb lymphoproliferativ megbetegedés, hypogammaglobulinaemia és bármely csontvelői sejtvonal cytopeniája is manifesztálódhat. Ebben a betegcsoportban az allogénőssejt-átültetés jó terápiás lehetőség.

\section{Speciális szempontok a PID-es betegek malignitásainak kezelésekor}

A gyermekkori rosszindulatú daganatok kezelése hazánkban egységes irányelveket követve, nemzetközi protokollok alapján zajlik. PID-es betegek számára nincsenek külön protokollok, azonban egyes betegcsoportoknál mind a kemo-, mind a sugárkezelésnél bizonyos speciális szempontokat figyelembe kell venni. A PID-es betegekből izolált malignus sejtek gyógyszer-rezisztenciája nem tér el a nem PID-es betegekétől. A PID-es gyermekekben előforduló malignitások döntő része agresszív, gyorsan progrediáló forma. Ennek megfelelően nagy dózisú, gyakran myelotoxicus kemoterápiás kombináció szükséges a gyógyításukhoz, amely után fokozottan kell súlyos, akár életet veszélyeztető fertőzések előfordulásával számolni. A CD20-pozitív sejtekből kiinduló daganatok célzott, monoclonalis ellenanyag kezelésével (rituximab) egyre több tapasztalatunk van, és kimondottan jó eredmények mutathatók fel. A Pneumocystis jirovecii okozta pneumonia profilaxisára sikeresen alkalmazzuk a trimetoprim-szulfametoxazol profilaxist hematológiai malignitás miatt kemoterápia alatt álló gyermekeknél. PID-es betegekben emellett felmerül antifungális és/vagy antivirális profilaxis szükségessége is. A fokozott kromoszómatörékenységgel járó szindrómák esetében a betegek extrém érzékenyek ionizáló sugárzásra, így ezen betegségcsoportban a sugárkezelést mint onkoterápiás módszert csak végszükség esetén alkalmazzuk, és akkor is a lehető legalacsonyabb terápiás dózissal. Alkilálószerek, podofillotoxinok, topoizomerázgátlók használatát, amennyiben megoldható, ebben a betegcsoportban kerülni kell [39]. Itt említjük meg, hogy ugyancsak ezen betegeknél a radiológiai diagnosztikus vizsgálatok indikálásakor is figyelembe kell venni a fent említett sugárérzékenységet. Egyes megfigyelések szerint AT-s betegek esetében a súlyos fertőzéses szövődmények miatt a kemoterápia intenzitását több esetben csökkenteni kellett, és ennek következtében ezen betegek teljes gyógyulási esélyei is mérséklődnek. Az antitesthiánnyal járó PID-es betegek a malignitás kezelése alatt is rendszeresen igénylik az immunglobulinpótlást.

Immun checkpoint inhibitorok (például nivolumab, prebrolizumab, atezolizumab) használatával a különböző malignus megbetegedésekben egyre több tapasztalat gyưlik össze, és az indikációs területek várhatóan tovább bővülnek az immunológiai megbetegedésekhez társuló malignitásokkal is $[40,41]$.

A PID-es betegeknél előforduló malignitások kezelése az onkológus számára nagyobb kihívást jelent, de fontos kiemelni, hogy a speciális szempontokat figyelembe véve és a legújabb kezelési lehetőségeket használva ezen betegek malignitásai is jól gyógyíthatók.

Anyagi támogatás: A közlemény megírása anyagi támogatásban nem részesült.

Szerzői munkamegosztás: M. J.: A kézirat megszövegezése. K. G.: Szakmai felügyelet. A cikk végleges változatát mindkét szerző elolvasta és jóváhagyta.

Érdekeltségek: A szerzóknek nincsenek érdekeltségeik.

\section{Irodalom}

[1] Page AR, Hansen AE, Good RA. Occurrence of leukemia and lymphoma in patients with agammaglobulinemia. Blood 1963; 21: 197-206

[2] Maródi L. Modern view of primary immunodeficiencies. [A primer immundeficienciák modern szemlélete. Orvostovábbk Szle. 2017; 14: 36-43. [Hungarian]

[3] Boyle JM, Buckley RH. Population prevalence of diagnosed primary immunodeficiency diseases in the United States. J Clin Immunol. 2007; 27: 497-502.

[4] Jonkman-Berk BM, van den Berg JM, Ten Berge IJ, et al. Primary immunodeficiencies in The Netherlands: national patient 
data demonstrate the increased risk of malignancy. Clin Immunol. 2015; 156: 154-162.

[5] Kersey JH, Shapiro RS, Filipovich AH. Relationship of immunodeficiency to lymphoid malignancy. Pediatr Infect Dis J. 1988; 7(5 Suppl): 10-12.

[6] Vajdic CM, Mao L, van Leeuwen MT, et al. Are antibody deficiency disorders associated with a narrower range of cancers than other forms of immunodeficiency? Blood 2010; 116: 12281234.

[7] Notarangelo LD. PIDs and cancer: an evolving story. Blood 2010; 116: 1189-1190.

[8] Gross TG, Shiramizu B. Lymphoproliferative disorders and malignancies related to immunodeficiencies. In: Pizzo PA, Poplack DG. (eds.) Principles and practice of pediatric oncology. Lippincott Williams \& Wilkins, Philadelphia, PA, 2006; pp. 748-767.

[9] Hauck F, Voss R, Urban C et al. Intrinsic and extrinsic causes of malignancies in patients with primary immunodeficiency disorders. J Allergy Clin Immunol. 2018; 141: 59-68.

[10] Erdôs M, Tóth B, Juhász P, et al. Nijmegen Breakage syndrome. [Nijmegen-Breakage-szindróma.] Orv Hetil. 2010; 151: 665673. [Hungarian]

[11] Janssen A, van der Burg M, Szuhai K, et al. Chromosome segregation errors as a cause of DNA damage and structural chromosome aberrations. Science 2011; 30: 1895-1898.

[12] Carbone A, Gloghini A, Dotti G. EBV-associated lymphoproliferative disorders: classification and treatment. Oncologist 2008; 13: $577-585$.

[13] Cohen JI. Primary immunodeficiencies associated with EBV disease. Curr Top Microbiol Immunol. 2015; 390: 241-265.

[14] Shapiro RS. Malignancies in the setting of primary immunodeficiency: implications for hematologists/oncologists. Am J Hematol. $2011 ; 86$ : 48-55.

[15] Seidemann K, Tiemann M, Henze G, et al. Therapy for nonHodgkin lymphoma in children with primary immunodeficiency: analysis of 19 patients from the BFM trials. Med Pediatr Oncol 1999; 33: 536-544.

[16] Shabani M, Nichols KE, Rezaei N. Primary immunodeficiencies associated with EBV-induced lymphoproliferative disorders. Crit Rev Oncol Hematol. 2016; 108: 109-127.

[17] Robison LL, Stoker V, Frizzera G, et al. Hodgkin's disease in pediatric patients with naturally occurring immunodeficiency. Am J Pediatr Hematol Oncol. 1987; 9: 189-192.

[18] Sandoval C, Swift M. Hodgkin disease in ataxia-telangiectasia patients with poor outcomes. Med Pediatr Oncol. 2003; 40: $162-166$.

[19] Suarez F, Mahlaoui N, Canioni D, et al. Incidence, presentation, and prognosis of malignancies in ataxia-telangiectasia: a report from the French national registry of primary immune deficiencies. J Clin Oncol. 2015; 33: 202-208.

[20] Reiman A, Srinivasan V, Barone G, et al. Lymphoid tumours and breast cancer in ataxia telangiectasia; substantial protective effect of residual ATM kinase activity against childhood tumours. Br J Cancer 2011; 105: 586-591.

[21] Jerzak KJ, Mancuso T, Eisen A. Ataxia-telangiectasia gene $(A T M)$ mutation heterozygosity in breast cancer: a narrative review. Curr Oncol. 2018; 25: el76-e180.

[22] Ambrose M, Gatti RA. Pathogenesis of ataxia-telangiectasia: the next generation of ATM functions. Blood 2013; 121: 40364045 .

[23] Resnick ES, Cunningham-Rundles C. The many faces of the clinical picture of common variable immune deficiency. Curr Opin Allergy Clin Immunol. 2012; 12: 595-601.
[24] Gangemi S, Allegra A, Musolino C. Lymphoproliferative disease and cancer among patients with common variable immunodeficiency. Leuk Res. 2015; 39: 389-396.

[25] Mayor PC, Eng KH, Singel KL. Cancer in primary immunodeficiency diseases: cancer incidence in the United States Immune Deficiency Network Registry. J Allergy Clin Immunol. 2018; 141: 1028-1035.

[26] Salavoura K, Kolialexi A, Tsangaris G. Development of cancer in patients with primary immunodeficiencies. Anticancer Res. 2008; 28: 1263-1269.

[27] Wheat WH, Cool CD, Morimoto Y, et al. Possible role of human herpesvirus 8 in the lymphoproliferative disorders in common variable immunodeficiency. J Exp Med. 2005; 202: 479-484.

[28] Snapper SB, Rosen FS. The Wiskott-Aldrich syndrome protein (WASP): roles in signaling and cytoskeletal organization. Annu Rev Immunol. 1999; 17: 905-929.

[29] Coppe A, Nogara L, Pizzuto MS. Somatic mutations activating Wiskott-Aldrich syndrome protein concomitant with RAS pathway mutations in juvenile myelomonocytic leukemia patients. Hum Mutat. 2018; 39: 579-587.

[30] Sullivan K, Mullen C, Blaese R. A multiinstitutional survey of Wiskott-Aldrich syndrome. J Pediatr. 1994; 125: 876-885.

[31] Imai K, Morio T, Zhu Y. Clinical course of patients with WASP gene mutations. Blood 2004; 103: 456-464.

[32] Picard C, Mellouli F, Duprez R. Kaposi's sarcoma in a child with Wiskott-Aldrich syndrome. Eur J Pediatr. 2006; 165: 453-457.

[33] Bosticardo M, Marangoni F, Aiuti A. Recent advances in understanding the pathophysiology of Wiskott-Aldrich syndrome. Blood 2009; 113: 6288-6295.

[34] Pai SY, DeMartiis D, Forino C, et al. Stem cell transplantation for the Wiskott-Aldrich syndrome: a single-center experience confirms efficacy of matched unrelated donor transplantation. Bone Marrow Transplant. 2006; 38: 671-679.

[35] Cirillo E, Giardino G, Gallo V. Severe combined immunodeficiency - an update. Ann N Y Acad Sci. 2015; 1356: 90-106.

[36] Morra M, Howie D, Grande MS. X-linked lymphoproliferative disease: a progressive immunodeficiency. Annu Rev Immunol. 2001; 19: 657-682.

[37] Rezaei N, Hedayat M, Aghamohammadi A. Primary immunodeficiency diseases associated with increased susceptibility to viral infections and malignancies. J Allergy Clin Immunol. 2011; 127: 1329-1341.

[38] Booth C, Gilmour KC, Veys P. X-linked lymphoproliferative disease due to SAP/SH2D1A deficiency: a multicenter study on the manifestations, management and outcome of the disease. Blood 2011; 117: 53-62.

[39] Seidemann K, Henze G, Beck JD, et al. Non-Hodgkin's lymphoma in pediatric patients with chromosomal breakage syndromes (AT and NBS): experience from the BFM trials. Ann Oncol. 2000; 11: 141-145.

[40] Ghelli Luserna di Rora A, Iacobucci I, Martinelli G. The cell cycle checkpoint inhibitors in the treatment of leukemias. J Hematol Oncol. 2017; 10: 77.

[41] Verhoeven D, Stoppelenburg AJ, Meyer-Wentrup F, et al. Increased risk of hematologic malignancies in primary immunodeficiency disorders: opportunities for immunotherapy. Clin Immunol. 2018; 190: 22-31.

(Müller Judit dr., Budapest, Tüzoltó u. 7-9., 1094 e-mail: muller.judit@med.semmelweis-univ.hu) 